\title{
鍼炎学校卒業後の進路と実態調査 (II)
}

(社)日本銊炎師会・(社)全日本鍼炎学会に対する意識調査

\section{藤 原 秀 雄 ${ }^{*}$}

\section{I はじめに}

鍼炎に対する社会的評価の高まる中で，毎年多 くの銊炎師が誕生し, 診療に従事している。これ ら，卒業間もない鍼炎師が，(社)日本銊尒師（以下 日針会)・学術団体である(社)全日本鍼炎学会 (以下 学会）について，どれほどその活動を理解し，い かに自己の職業と密接に関連づけているのかは不 明である。また，新しく鍼尒を職業として選択し た彼らが，現在の鍼炎のあり方・今後鍼炎師が進 むべき方向性についてどう考えているかは，まだ 調査されていない。

今回，われわれは，日針会・学会に対して卒後 間もない彼らが何を求めているか，又何を希望し ているかを調査し，今後の日針会および学会活動 の方向性を考える上での資料とするため，アンケ 一ト調査を行なったので若干の考察を加え報告す る。

\section{II 対象と方法}

今回の調查は, 昭和 56 年 $\cdot 57$ 年・ 58 年度の入手 可能であった鍼炎学校卒業者名簿より, 無作為に 抽出した 1,000 名を対象とした。

アンケート用紙(表 1 )は, 各自に郵送し回収し た。

調查回収期間は，昭和58年 10 月より昭和 59 年 4 月までとした。

\section{III 結 果}

1）回収状況：アンケート回答者の地域分布は, 近畿地方を中心にほぼ全国的であった。アンケー 卜郵送数1,000, 回収 288 , 回収率 $28.8 \%$ であった

* Hideo FUZIWARA 岡山大学附属病院麻醉科
表 1 アンケート

（1）日本鍼炎師会・全日本鍼炎学会についてお答え 下さい。

1. 日本銊炎師会

○会員・非会員について
a）会員になっている。
b ）会員でない。

2. 全日本銊炎学会

○会員・非会員について
a）会員になっている。
b ）会員でない。

○学会について
a ）学会は，会員の利益のためになっている。
b ）学会は, 無意味な存在である。
c）わからない。

○学会について
a ）学問的活動をもっとすべきである。
b ）学会員の利益の向上をもっと計るべきで ある。
c）会員にわかり易い活動をしてほしい。
d）その他。

（2）日本銊炎師会・全日本鍼炎学会について，御意 見があればおきかせ下さい。

1. 日本銊炎師会について。

2. 全日本鍼炎学会について。

（3）現在の鍼尒師のあり方について，御意見があれ ばおきかせ下さい。

2）所属の有無：日針会所属の有無（図 1・a )に ついては，288名中266名が回答し，会員が52名(18 $\%)$ ・非会員 214 名 $(74 \%)$ と入会率が低かった。

学会所属の有無 (図 1・b ) については, 288名中 256 名が回答し，会員が25名 $(8.7 \%) \cdot$ 非会員 231 名 $(80 \%)$ とこれも入会率が低かった。

3）学会についての意見および希望 (図2 a・b): 学会に対しての意見では, 学会は会員の利益にな 
図 1 所属の有無（会員・非会員）

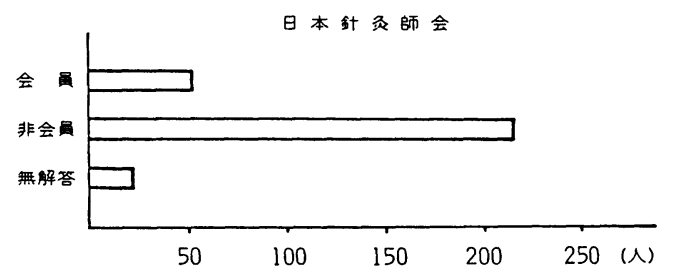

(図 1 a )

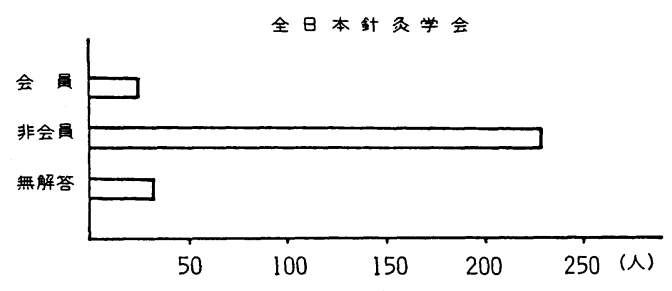

(図 $1 \cdot b$ )

図2 学会についての意見および希望

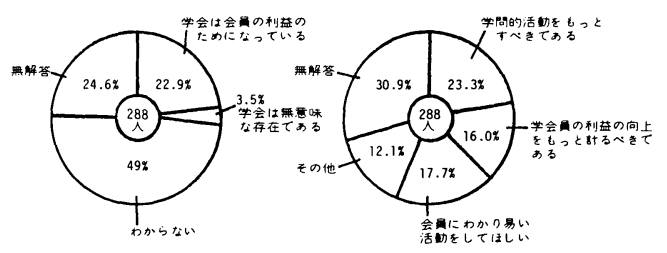

(図2 a )

(図2 b )

つていると答えたものが $22.9 \%$ あるる反面，学会 活動がわからないと答えたものが $49 \%$ と非常に多 かった。

学会に対しての希望としては, 学問的活動をも っとするべきであると答えたものが $23.3 \%$ と最も 多く，このほか，会員にわかり易い活動をして欲 しいと答えたもの $17.7 \%$ ，学会員の利益の向上を

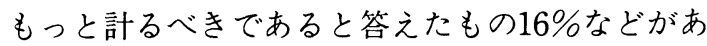
った。

4）日針会・学会についての意見（表2）：日針会 に対しての意見・希望は, 288名中84名が回答し， 組織活動の充実および啓蒙不足を訴之るものが38 件と最も多く，ついで，保険の運用に関する問題 の早期解決を望むものが23件, 保険問題の障害と なっている団体の統一化を望むものが21件であっ たが，会費が高くメリットが少ないと答えたもの

表2 日鍼会・学会についての意見

(社)日本銊炎師会についての意見。

(84名)

1. 組織活動の充実及びピーアール不足 (38件)

2. 保険問題の早期解決

(23件)

3. 団体の統一化

(21件)

4. 会費が高くメリットがない

5. その他

(36名)

(10件)

1. 学会に対する理解不足

2. 学術大会に対する意見及び期待

3. 会員に対する学会の指導力の強化

4. 保険問題の早期解決

5. その他

も 9 件あった。

学会に対しての意見・希望は,288名中36名と非 常に少なかった。学会運営に関しては, 学会活動 に対する理解不足10件・会員に対する学会の指導 力の強化を望むもの 9 件があった。学術に関して は，学術大会に対する意見および期待が10件あっ た。また，直接学会活動とは関係はないが保険問 題の早期解決を望むものも 3 件あった。

5）現在の鍼炎師のあり方（表3）: 学問・教育に 関する意見が56件で最も多く，西洋医学的知識・ 技能を身につけたいという希望が多かった反面, 本来の東洋医学古典の知識・技能を修めるべきだ

表3 現在の鍼炎師のあり方について
A．学問・教育に関する意見（56件）
○東西医学の知識の向上
○卒後の学問の場が少ない
○学校教育のカリキュラムの充実
B. 銊炎師の社会的地位に関する意見（35件）
○現代医療体系の中での鍼炎師の身分の確立
○鍼炎独自の医療体系の確立
○銊尒医学の啓蒙不足
C．鍼炎学のあり方に関する意見（32件）
○古典治療の充実
○医師と協力しての鍼炎治療
○信頼される銊炎師へ
D. 保険問題 (27件)
○保険制度の全面的な早期運用
○団体の統一化 
という意見もかなりあった。また，卒後研修の機 会・学校教育における教育内容の充実を求める意 見もみられた。

鍼炎師の社会的地位向上に関する意見は35件あ $\eta$, 現代医療体系の中における銊尒師の身分の確 立を求める意見・鍼炎独自の医療体系の確立を求 める意見などがあった。また，社会・国民に対す る鍼炎医学の啓蒙不足を指摘する意見もみられた。 銊炎医学のあり方に関する意見は32件あり，診療 に対する自己の方向性として，古典治療の充実を あげるもの，地域の医療機関と連携を持った鍼炎 治療院経営をしたいもの，患者と信頼関係のある 銊炎師を目指すものなどがあった。保険問題に関 する意見は27件あり，団体の統一化を図ることに より保険制度の早期確立を期待する意見がある反 面，反対する意見が一部にあった。

\section{IV 考 察}

全国に銊尒師は約50,000名おり ${ }^{2)}$ ，両会への加入 状況は，日針会に所属する者は約6,000名 (12\%) であり゙，学会に所属する者は約 2,800 名 $(5.6 \%)$ である゙)。

今回の調査では, 回収数 288 名中, 日針会への入 会者は 52 名 $(18.1 \%)$, 学会への入会者は 25 名 $(8.7$ \%)であった。両会への加入状況は，少ないながら も増加の傾向にあると考之られる。

両会への加入の少ない原因としては，今回のア ンケートから考えられることは，日針会について は,「組織活動の啓蒙不足」「会費が高くメリット が少ない」, 学会については，「学会は無意味な存 在である」「わからない」という意見がみられるよ うに，両会とも会員に対し，その組織活動の意義 ・目的などの啓蒙不足や指導性の弱さがあげられ る。又両会に対する意見の少ないことから，両会 の組織活動に対し，無関心な銊尒師が非常に多い ことが推察できる。これら組織活動に全く興味を 示さない銊尒師を，今後いかにして日針会・学会 活動に参加させるかが, 両会に科せられた今後の 課題であり，かつ日針会会員・学会会員の任務で はないだろうか。

日針会は，鍼炎学術の進歩発展・国民の福祉・ 鍼炎師の資質の向上と福祉などを目的として活動
を行ない，会員のみならず鍼苂師全体の利益向上 のため，その役割をはたしていかなければならな いと考えられる5)。しかし，卒後間もない人々が日 針会に希望している，組織活動の充実・保険問題 の早期解決などは，会員の総力によってなされる ことである。これらの事を実現するためにも，卒 後間もない人々が，積極的に会員となり，互いに 協力し，組織力の強化を計って行かなければなら ないのではなかろうか。また，日針会自体も銊尒 の専修学校・盲学校などの教育機関・その他の機 関を通じ，日針会の目的・活動状況を今以上にア ピールして行く必要があるのではないだろうか。

学会は, 鍼尒医学に関する研究発表および知識 交換の場であり，鍼炎医学の発展を目的とする学 術団体である。しかし，学会への加入が少ないと いう事実や「学会活動に対する理解不足」という 意見があることなどから, 学会の活動および内容 が十分に理解されていないことが考えられる。こ のことを打壊して行くためには，まず，学会が今 以上に地方会の組織力を高め, 組織活動の充実を 計り指導して行く必要があるのではなかろうか。

現在の鍼炎師のあり方については，個々の銊尒 師が改善し，かつ協力して行かなければならない 点が指摘されている。卒後研修に関しては, 現代 医療の中での新しい銊尒の方向性を模索している 部分がうかがわれる。すなわち，病院勤務鍼炎師 は，医師と協力し病院の中に鍼炎をとり入れ，ま た，鍼尒院勤務および開業鍼尒師は，古典鍼尒を もとにした診療の充実を図りつつ, 周囲の医療機 関と連携を保ちながら診療に従事しているものも 少なくない。

このように，医師と協力しながら医療を進めて 行くためには，東洋医学的知識だけでは十分でな く, 西洋医学的知識・技能を積むことも大切なこ とである。しかし，このように東西医学に対する 学習意欲がうかがわれる, 卒後間もない銊苂師た ちの「学問の場が少ない」という意見から，日針 会・学会等が今以上に教育指導をして行く必要が あると考えられる。

銊尒学校における教育については, 鍼炎医学が 医療の中に取り入れられ，社会的にも評価を受け てきた中で，医療状況に即応した体制の確立が求 
められている。すなわち，全国の銊尒師養成機関 としては, 専修学校・盲学校の専攻科・銊尒大学 などがあり $\eta^{6)}$ ，毎年約 2,200 名が卒業しているが， 鍼尒を今以上に社会のニーズに答えさせるために は，現在の教育制度では十分でなく，銊尒大学を 初めとした教育体制の確立を計り推進して行く事 が必要であろう。

これらのことがなされれば銊炎師の社会的地位 向上・信頼される鍼尒師ということにもつながっ て来るのではないだろうか。

保険問題については，卒後間もない銊尒師が生 計を立てて行く上で特に関心があり，日針会が行 なった調査「保険取扱意志の有無について」では 95.5\%の者が取り扱う意志を示していた は反対する意見もあるが，早期確立を望む声が多 く銊炎師・組織が団結して，団体の統一化を図り 組織未加入者をなくし，共に保険問題に対応して 行く必要がある。

学会の仕事は, 鍼炎医学の発展を計ることが主 務であるが，学術大会での業績をもとに銊尒医学 をさらに確立発展させ，銊炎教育をさらに改善し 国民の健康維持・増進のため, 学会は大きな強い 組織にならなければならないであろうと考えられ $3^{8)}$ 。又両会は，鍼炎の教育機関を通じて，両会の 実態・活動状況を今以上に理解してもらい, 入会 の呼びかけをして行く必要がある。

卒後間もない鍼尒師は, 西洋医学的知識と技能 の向上及び現代医療との協力体制を望んでいる者 が多い反面，古典の学習・鍼尒師の独自性を持つ べきだという主張もかなりあった。しかし，現在 の社会情勢から考之て, 現代医学に協力・協調し て行くことは不可欠なことではないだろうか。

以上，不十分な調査報告となったが，今回の反 省の上に立って，今後もこの問題について考えて 行きたい。

\section{$\mathrm{V}$ 結 語}

卒後間もない鍼炎師に対し，鍼炎学校卒業後の 進路と実態調查を行い，日針会・学会に対する意 識調査および鍼炎師のあり方についてアンケート を行なった。

卒後間もない鍼尒師は，日針会・学会ともに入
会率が低かった。また，日針会・学会に対しての 意識調査も低かった。このことは，日針会および 学会は今後, 会務の実態, 活動状況をより充実さ せ，鍼炎師の興味のあるものになっていく必要が あると同時に，会員一人一人が両会を充実させ又 両会は会員にメリットのあるものにしていく必要 があると考えられる。

最後に, 今回の調查に御指導・御助言を賜りました 岡山大学医学部麻酔学教室の宮崎峰生先生, 古谷生先 生に深く感謝申し上げます。

\section{引用文献}

1) 本田泰弘：銊炎学校卒業後の進路と実態調査( I ), 全日本銊尒学会雑誌, 投稿中。

2）善徳泰博：国会におけるはり・きゅうに関する質疑 応答。医道の日本日本, $477,122 .(1984)$

3）58年度会員異動状況：日本銊尒新報，264, 9. (1984)

4）医学便覧：(社)全日本鍼炎学会, カネボー薬品KK, 113. (1984)

5）黑須幸男：全日本銊炎学会の今後の方向, 銊炎学会 報，フ，4.（1982）

6）谷口健蔵：明治鍼炎大学の開学にあたって, 日本銊 炎新報，252，フ.（1983）

7）山下 健：銊尒の医療保険取扱いの現状報告, 日本 鍼炎新報，251，フ，(1983）

8）中村万喜男：学会・教育・医療保険は無縁ではない, 日本鍼炎新報，12，4（1984）

(干700 岡山市春日町4-23) 